\section{EMBRYRIDDLE}

Aeronautical University

SCHOLARLY COMMONS
Journal of Aviation/Aerospace Education \& Research

Volume 12

Number 2 JAAER Winter 2003

Article 3

Winter 2003

\title{
Aviation Opportunities in Ecotourism
}

Mary M. Snow

snowm@erau.edu

Richard K. Snow

snow4fc@erau.edu

Follow this and additional works at: https://commons.erau.edu/jaaer

\section{Scholarly Commons Citation}

Snow, M. M., \& Snow, R. K. (2003). Aviation Opportunities in Ecotourism. Journal of Aviation/Aerospace Education \& Research, 12(2). https://doi.org/10.15394/jaaer.2003.1580

This Article is brought to you for free and open access by the Journals at Scholarly Commons. It has been accepted for inclusion in Journal of Aviation/Aerospace Education \& Research by an authorized administrator of Scholarly Commons. For more information, please contact commons@erau.edu. 


\title{
AVATION OPPORTUNITIES IN ECOTOURISM
}

\author{
Mary M. Snow and Richard K. Snow
}

\begin{abstract}
Ecotourism is a specialized form of tourism designed to allow the exploration of unique natural and cultural areas while creating a positive impact on local communities. As the primary mode of international transportation, aviation stands to benefit further from the burgeoning ecotourism market. This paper presents data that demonstrate the unprecedented growth of ecotourism in recent years and suggests opportunities the industry offers those in the field of aviation. Also discussed is the potential for achieving a greater degree of economic and ecologic sustainability for ecotour destinations.
\end{abstract}

\section{Introduction}

Tourism is one of the largest industries on the planet, accounting for approximately 11 percent of the global Gross Domestic Product (GDP), employing nearly 200 million people, and transporting approximately 700 million travelers worldwide (Roe \& Urquhart, 2001). Further, in Tourism After 11 September 2001: Analysis, Remedial Actions and Prospects, the World Tourism Organization (2001) estimates that by the year 2010, the number of international travelers will reach 1 billion and 1.6 billion by the year 2020 .

The fastest growing segment of the tourism industry is travel to natural or cultural areas, also known as ecotourism (Eblen \& Eblen, 1994). The United Nations declared 2002 as the International Year of Ecotourism, and the first World Ecotourism Summit was held in Quebec City in May 2002 with more than 1,100 delegates attending from 133 countries. The Ecotourism Society $(1991$, p. 1) defines ecotourism as

purposeful travel to natural areas to understand the culture and natural history of the environment, taking care not to alter the integrity of the ecosystem, while providing economic opportunities that make the conservation of natural resources beneficial to local people.

Similarly, the International Ecotourism Society defines ecotourism as "responsible travel to natural areas that conserves the environment and sustains the well being of local people" (2002). Such definitions recognize duties to future generations while acknowledging the needs of people present today.

When ecotourism is managed in accordance with these principles, it represents an ecologically, culturally, and economically sustainable industry. This degree of sustainability generates revenue without degrading the environment or a local society's traditional way of life. This is not to suggest that a local culture is not altered in any way, for new development inevitably is accompanied by transformation. Rather, the goal of responsible ecotourism is to minimize negative impacts so that cultural customs along with relatively pristine places are preserved as much as possible.

As the main means of international transportation, aviation plays a dominant role in ecotourism. In the wake of recent events, some aviation students and professionals have questioned the future of the industry. Ecotourism provides a niche that can satisfy some of these doubts while appealing to the spirit of adventure that many aviators enjoy.

\section{Ecotourists}

A survey conducted by The U.S. Travel Data Center in 1991 ("Discover America," 1992), indicated that seven percent of travelers in the United States had been on an ecotour, and within the following three years another 30 percent planned to take such a trip. A profile of ecotourists reveals that of the eight million American ecotravelers, almost half earn more than $\$ 40,000$ annually. The majority of ecotourists are from the Great 
Lakes region and the West ("Discover America," 1992). Ecotourists typically are 35 - 54 years old, and 82 percent are college graduates. They are comprised of an equal ratio of males to females, have traveled internationally previously, and are concerned about the environment (Kutay, 1991).

Ecotourists take longer trips ( 8 - 14 days) and tend to spend twice as much more per day than tourists who say that nature is not an important aspect of their travel. It is estimated that ecotourists in Latin America spend \$1000 more during a two-week stay than traditional tourists (Godwin, 1991). The International Ecotourism Society (2002) notes that among experienced ecotourists, the most desirable element of a tour is a secluded, wilderness setting. Such environments often are accessible only by aircraft. Based on this profile of the ecotourist, it seems one avenue for economic recovery and growth in the aviation industry might well be in appealing to the informed ecotraveler.

\section{Opportunities}

The idea of leaving the usual routine to board a plane and fly to an exotic location is not new. Since the early days of commercial aviation, people have embarked on such adventures. Today, many of the destinations desired by ecotourists are located in remote areas unaccustomed to accommodating foreigners. However, the lack of the usual facilities does not seem to discourage many of the current ecotravelers. Nature tourists are less demanding than traditional tourists and believe that an essential part of the trip is experiencing life with the locals including the foods, customs, and overall living conditions to a certain degree. Because ecotourists generally do not expect lavish amenities, almost any area of natural or cultural significance offers tremendous opportunities for aviation and the local community.

Air transport facilitates mobility and accessibility from a region's core to its periphery. For instance, those who live and work in the large, industrialized regions of the United States are able to visit the glaciers of Denali National Park or observe the migration of caribou herds across the Alaskan Coastal Plain. However, tourism places certain demands on the host government to invest in and maintain essential infrastructure.

There is an obvious need for transportation infrastructure in any society that plays a part in the global economy. In general, transport functions as a centripetal force and is a principal tool for development, helping to spatially integrate all parts of the world. At this global level, air travel dominates the flow of people and goods. Without an airport, many of the more exotic, remote, and therefore desirable locations would be inaccessible.

Often viewed as a major indicator of the prosperity of a region, it is usually surmised that if the local airport is thriving, the surrounding area will be flourishing as well. Although ground transportation, communications, and lodging facilities are necessary, without the airport or airstrip there would be little need for additional infrastructure. As the aircraft commands a quintessential role in ecotourism, the airport serves as the fundamental gateway from one environment to the next. Although smaller commuter aircraft eventually arrive at an ecotour destination, the initial transfer of tourists typically requires the use of a larger airport. From regional or international airports, visitors begin to access even the most remote natural and cultural areas. Thus, an economic window of opportunity is opened for less developed communities to participate in the global economy, even if local transportation infrastructure is somewhat deficient. Similarly, opportunities are created for aviation and travel industry professionals to engage in nontraditional enterprises.

For example, one South African tour operator describes departing Lanseria Airport in Johannesburg aboard a fast, twin-engine aircraft with the pilot/guide to fly to Sossusvlei Wilderness Camp in the heart of the Namib Desert. From the base camp, the tour traverses the dunes of the Namib before flying over the lush landscape of the Okavango Delta and on to the Moremi Game Reserve in northern Botswana.

Another operator details a safari to Nairobi designed to take travelers off the beaten track and provide a high quality wildlife experience tracking prides of lions from a base in a luxury tented camp at the foot of Mt. Kilamanjaro. It appears that if nature lovers are prepared to pay thousands of dollars to sleep in tents, the sky is the limit as far as developing ecotours is concerned. With only a minimum of accommodations necessary to begin operating, the local community and those who provide services to the ecotour industry, such as pilots and support personnel, could succeed in or near almost any area large enough to facilitate aircraft operations.

Some operators engage in ecotour activities 
even without the benefit of an airport. One particular aviation company flies visitors to remote and inaccessible areas of Canada, the Caribbean, and Central America. Among the aircraft in its fleet are a Cessna C-206 and a DeHavilland Beaver, both of which are float equipped. The owners assert they are dedicated to offering unique ecotourism services. Flying into natural areas that only can be reached by floatplane exemplifies this ideal.

Universities and colleges also recognize that ecotourism is a component of tourism that is flourishing to become a formidable factor in the travel industry. Subsequently, it is imperative to effect an understanding of ecotourism, its goals, and how these can be attained. The best way to achieve this end is through the transfer of knowledge within the realm of academia concerning the field of ecotourism.

In 1995, schools including George Washington University, the University of Wisconsin, and Yale University offered courses in ecotourism (Robertson, 1995). Today this list has increased to include Michigan State, Penn State, and Cornell University. In many cases, ecotourism is integrated into other courses available in departments such as Geography, Environmental Studies, Forestry, Recreation Management, or Natural Resources. Such inclusion into the curricula by major institutions of higher learning helps confirm that ecotourism is a discipline worthy of research and training. Appendix A lists a number of universities and colleges that offer courses in ecotourism.

For aviation professionals or graduates desiring to find employment within some facet of the ecotour industry, there are a variety of placement services available. One agency is an enthusiastic advocate of wildlife-related tourism. Its web-site presents a brief history of ecotourism citing examples from Kenya, Costa Rica, and other exotic destinations. For a nominal fee, the agency will send an individual's resume to employers in all areas of the aviation industry, from baggage handlers to pilots.

\section{Growth Analysis}

There is little doubt that the travel industry is experiencing unprecedented growth and promises to continue to be a significant economic force. In 1998, residents of and international travelers to the United States spent an average of $\$ 1.36$ billion a day on tourism ("Travel Industry," 1999). The Adventure Travel Society
(2002) reports that approximately half of this revenue is generated by ecotourists, which includes transportation, lodging, food, and equipment, and there are more than 10,000 adventure travel operators in the United States. A sampling of ecotour operators is found in Appendix B.

Reingold (1993) estimates that while the tourism industry in general has been growing at a rate of 4.6 percent annually, ecotourism has experienced annual growth rates between 10 and 30 percent in recent years. Lindberg (1997) reports similar findings for the AsiaPacific region with nature travel growth rates of 10 to 25 percent.

While no global institution is gathering statistics on the ecotourism market, it is estimated that $\mathbf{5 0}$ percent of all international tourists can be defined as nature tourists who travel to experience the outdoors, and 30 percent can be classified as wildlife-related tourists, such as bird watchers (Fillion, 1994). Based on this estimation, it is possible to approximate the growth rate of the number of persons participating in either nature travel or wildlife-related activities (table 1).

Handszuh (2001) states that in 1999 international tourism generated $\$ 548$ billion accounting for over $\mathbf{4 0}$ percent of internationally traded services, and the transportation of tourists earned $\$ 93$ billion or 17 percent of this total. Additionally, 83 percent of all countries list tourism as one of their top five export categories, and 38 percent declare tourism as their main source of foreign exchange earnings.

Regarding air transportation, Handszuh (2001) notes that the World Tourism Organization cites aviation as the primary mode of travel for approximately 56 percent of international tourists to Africa, the Americas, the Middle East, and the East Asia-Pacific realm, while 80 percent of tourists visiting South Asia arrive by air. These data suggest a continued increase in the number of ecotourists, and those in the aviation industry are poised to partake in this expansion. 
Table 1. Tourism Growth 1988-2020 (Fillion, 1994; "Tourism After," 2001)

\begin{tabular}{rrrr} 
& $\begin{array}{c}\text { International } \\
\text { Tourists }\end{array}$ & $\begin{array}{c}\text { Nature } \\
\text { Tourists }\end{array}$ & $\begin{array}{c}\text { Wildlife-Related } \\
\text { Tourists }\end{array}$ \\
\hline 1988 & $393,000,000$ & $197,000,000$ & $118,000,000$ \\
\hline 1990 & $457,000,000$ & $229,000,000$ & $137,000,000$ \\
\hline 1994 & $528,000,000$ & $264,000,000$ & $158,000,000$ \\
\hline 1997 & $595,000,000$ & $298,000,000$ & $179,000,000$ \\
\hline 2000 & $696,000,000$ & $348,000,000$ & $209,000,000$ \\
\hline $2010 *$ & $1,006,000,000$ & $503,000,000$ & $302,000,000$ \\
\hline $2020 *$ & $1,561,000,000$ & $781,000,000$ & $468,000,000$ \\
\hline
\end{tabular}

* Projected

\section{The Costs}

While economic advances in ecotourism are being realized, these opportunities require responsible action and consideration regarding the impacts that increasing numbers of visitors could have on fragile ecosystems. Although tourism growth normally is an asset, it soon becomes a liability if the capabilities of the infrastructure, such as communications, water, transportation, and sanitation facilities, are exceeded. Factors that can produce negative impacts on a natural area due to a rising number of tourists include noise, garbage, excessive water consumption, and habitat loss. Although these consequences are dire, proper planning and responsible management can provide substantial protection against such environmental degradation.

Just as individual tour operators must make the right decisions in order to affect the future of the planet in a positive manner, airlines should seek to strike a balance between sustainability and profits. Otherwise, the time might arise when there are no natural areas left to visit. For example, the Galapagos Islands National Park located off the coast of Ecuador in South America is the oldest protected area in Ecuador, having achieved protection status in 1959. Accessible only by boat or air, most tourists choose to travel to the islands by aircraft, landing at Baltra or San Cristobal. The airport at Baltra has just the basic requirements necessary to accommodate the local military airline, which offers daily flights to the islands with a capacity of approximately 125 passengers per trip. However, San Cristobal is home to a newer airport that opened in 1986 and is serviced by a private airline (Boo, 1990).

Puerto Ayora on Santa Cruz Island is the capital of the Galapagos and serves as the center for lodging and touring in the islands. Once in Puerto Ayora, tourists transfer to cruise ships and visit various islands for periods lasting between 3 and 14 days. There also are numerous tour operators who use smaller vessels, such as windjammers, catering to the more hardy ecotourists groups of about a dozen. All boat tours must be approved by the National Forestry Administration, which issues the permits necessary to conduct business on the waterways of the Galapagos. In addition, the naturalist guides who work in the park must speak English and must have completed at least three years of university training in the natural sciences. Guides also must be well versed in the natural history of the islands, as well as the theory, history, and organization of the national parks (Boo, 1990).

Well aware of the impacts that the increase in nature adventurers could have on an environment as unique as the Galapagos, the government of Ecuador sought to control tourist numbers. While acknowledging that tourism is economically necessary as it provides jobs 
and funds for the protection of the park, Ecuadorian policy makers calculated the carrying capacity of the islands to be 25,000 visitors annually. This cap initially was enforced by the limited availability of lodging on cruise ships and by small, local hotels (Coe \& Gee, 1986). However, members of the Galapagos National Park Service claim that this carrying capacity was substantially exceeded. According to Boo (1990, p. 99), "unofficial statistics indicate that in 1986, when the San Cristobal airport was opened, the islands were flooded by almost 50,000 visitors a year, far beyond the officially established carrying capacity."

In order to address the problem of the growing number of tourists in the Galapagos, which could potentially destroy the islands' diversity and consequently the tourism industry, the government founded the Ecuadorian Ecotourism Association in 1991. This was the first organization of its kind in Latin America. The association provides a means of networking among its membership, which is comprised of educational institutions, naturalists, native groups, hotel owners, tour operators, and handicraft artists. The strategy is to bring the government and private sectors together in an effort to manage ecotourism activities and to advance the concept of sustainable development through environmental education (Munoz, 1993).

The cultural costs that can result from ecotourism are similar to those impacts from other sources of contact between outsiders and native people. Dr. Toni Hagen, who has trekked more than 10,000 miles across Nepal, remarks that "ecological damages are theoretically irreversible while the loss of cultural substance and identity is not" ("New Travel," 1995, p.1). Some historians point out that the socially and culturally disruptive exploitation of the developing world began with colonialism during the sixteenth and seventeenth centuries and extended into the twenty-first century. The social change that accompanied colonialism has been attributed to the industrialized world diffusing its culture onto various agrarian societies. However, the real characteristics of the colonial period were "dominance, subordinance, and dependence," which sometimes are seen today in the "cultural, economic, and political interaction between the developed and the so-called underdeveloped world" (Angeloni, 1992, p. 184).

Due to the depressed economies of many remote regions such as mountains and deserts, the local inhabitants are inclined to accept the negative aspects of tourism as a matter of survival. Once it is advertised that another natural area is open to ecotourism, outsiders tend to arrive in droves bringing cultural change, which is often for the worse. Ideally, the "people in such regions should take control of the process and find economic, cultural, and ecological balance" (Price, 1994, p. 35).

Thus, there are negative effects that can accompany ecotourism when tours are not properly managed and natural areas are not protected. The increase in visitors to these pristine sites could eventually destroy the fragile ecosystems and the local communities that make a place a desirable destination. The threat of unmanageable numbers of tourists exceeding the human carrying capacity and the danger of tour operators not exercising proper care remains eminent.

\section{The Benefits}

While unfavorable impacts can accompany careless nature travel, responsible ecotourism is meant to enhance rather than replace traditional ways of life in developing countries. As native people go about their usual routines, whether it is weaving, cooking, worshipping, or celebrating, visitors pay for the opportunity to observe or even participate in these cultural experiences. As a result, ecotourism can serve to stimulate economic prosperity while preserving traditional practices (Pearce, 1981).

In addition to the economic and cultural benefits that are enjoyed by a local community, often times there is increased protection for natural ecosystems. Parks or preserves with a higher volume of visitors generate more revenue and are able to improve planning and provisions afforded by the availability of additional funds. These benefits are best realized when local people have a voice in decision-making processes, such as to reinvest in their natural area. Typically, the region becomes a source of pride for the community and the efforts to preserve a unique ecosystem are furthered.

While developing countries are home to approximately 75 percent of the world's population, currently these nations enjoy only 30 percent of the world's international tourism market. However, since 1990 this market has grown by 9.5 percent a year in developing countries as opposed to the worldwide growth of approximately 4.6 percent (Roe \& Urquhart, 2001). At the 1999 meeting of the United Nations Commission on Sustainable Development, governments were urged to "maximize the potential of ecotourism for eradicating poverty by developing appropriate strategies in cooperation with all major groups, indigenous and local communities" (Roe \& Urquhart, 2001, p. 3). What has been termed Pro-Poor Tourism (PPT) is designed to focus on this goal.

PPT results in the creation of jobs, many of which go to women. While the number of jobs from PPT has increased over those provided by manufacturing, it is 
less than those provided by agriculture. As opposed to tourism that is dominated by either the private sector or by foreign interests, PPT includes: the participation of the informal sector, opportunities to sell hand-crafted wares while the customer comes to the product; and the provision of income from natural capital such as wildlife or scenery. These are riches that some of the world's poorest people have in the absence of financial assets.

For example, there are a variety of resources within a natural area such as the Amazon Rainforest, which is among the most biologically diverse environments in the world. Responsible stewardship of such natural areas entails curtailing growth so that this wealth of wildlife, wood, food, and medicines escape being exploited to extinction. When these areas are properly protected, the benefits can be far-reaching.

Additionally, natural areas also offer tremendous educational and research opportunities from the study of flora and fauna to the landforms that characterize a region. Children and adults gain a better understanding of the workings of the natural systems of the environment that often leads to a greater appreciation for the biosphere and our place in it. Apparently, there are cultural, historical, and aesthetic benefits from ecotourism that elude quantification and cost/benefit analyses.

Summary

One of the greatest advantages of air travel is the ability to quickly transport people from one environment to the next. The final destination may be a small village or unique natural area in some remote corner of the world. Once the local airport or landing strip has been established, isolation becomes a thing of the past as people in environmentally sensitive areas seek to sustain themselves and their cultures by allowing visitors to witness the splendor of their homelands and the richness of their rituals.

While, the inhabitants of these regions can be faced with choosing between exploitation for prosperity and preservation for posterity, this does not need to be the case. In words that still ring true thirty years later, Robert Fraser $(1972$, p. 4) describes the importance of developing positive attitudes concerning the role of aviation, which is vital when dealing with ecology minded nature tourists:

Attitudinal or social factors are those based on attitudes that people have adopted, whether for sound reasons or not. Because attitudes are often deep-rooted and irrational, they are difficult to change. Two important attitudinal factors constraining the development and implementation of new technology, are the widespread conviction that air transportation is important to only a small segment of the population; and that aircraft are noisy, a threat to the safety of populated areas, contribute to traffic jams, and create other objectionable conditions.

The airline industry should continue its efforts to convince the public that transportation by air has the potential to be beneficial for all, even for those who might never fly.

By providing reasonable airfares, those people with marginal incomes have the opportunity to visit unique cultural and natural areas as they help to dispel the myth that ecotourism is only for the elite. By enhancing rather than degrading the environment, ecotourists are encouraged to support the airline industry along with ecosystems. Finally, by adopting sound standards of sustainable development, aviation professionals involved with ecotourism can improve the chances for the people visited by air travelers to enjoy a higher quality of life.

Following the tragedies of terrorism, many people have been reevaluating the importance of family and friends. The need to spend memorable time together in a natural setting is more apparent. At the same time, curiosity of varying cultures and belief systems has increased. These factors suggest that the ecotourism market along with its support systems will continue to expand. However, to be true to its precepts, ecotourism must be based on education, awareness, appreciation, and concern for the futures of both biologically diverse lands and culturally rich communities.

Along with the responsibilities involved with the sustainability of ecotourism destinations, those involved in aviation are provided with tremendous possibilities. Not only are numerous opportunities available for the aviator seeking the road less traveled by, but also airport planners, engineers, maintenance technicians, safety personnel, and individuals with degrees in business administration have roles to play in ecotourism. In addition to fulfilling an inherent desire for adventure, aviation professionals can participate in the preservation of ancient cultures as well as lands that are invaluable to the future of the Earth system. 
Mary M. Snow holds a Ph.D. in Physical Geography with a minor in Life Sciences from Indiana State University. She earned a Master of Science degree in Geoscience and a Bachelor of Arts degree with a double major in Philosophy and Geography from Western Kentucky University. Mary is an Assistant Professor in the Department of Applied Aviation Sciences on the Daytona Beach campus of Embry-Riddle Aeronautical University and a licensed private pilot.

Richard K. Snow holds a Ph.D. in Physical Geography with a minor in Life Sciences from Indiana State University. He earned a Master of Science degree in Geoscience and a Bachelor of Science degree in Geography with a Philosophy minor from Western Kentucky University. Rich is an Assistant Professor in the Department of Applied Aviation Sciences on the Daytona Beach campus of Embry-Riddle Aeronautical University. 


\section{REFERENCES}

Adventure Travel Society. (2002). Retrieved June 14, 2002 from www.adventuretravel.com Angeloni, E. (Ed.). (1992). Anthropology 1992/1993 (p. 184). Guilford, CN: Dushkin Publishing. Boo, E. (1990). Ecotourism: The potentials and pitfalls. (Vol. 1-2). Washington, D.C.: World Wildlife Fund. Coe, E. \& Gee, C. (1986). Strategic tourism market plan for Ecuador. Washington, D.C.: GPO.

Discover America. (1992). Tourism and The Environment. Washington, D.C.: Travel Industry Association.

Eblen, R. A., \& Eblen, W. R., (Eds.). (1994). The encyclopedia of the environment (p. 730). New York: Houghton Mifflin.

Ecotourism Society Newsletter. (1991, Spring). (p. 1). Alexandria, VA.

Fraser, R. C. (1972). Civil aviation development: A policy and operations analysis (p. 4). New York: Praeger.

Fillion, F. L., Foley, J. P., and Jacquemot, A. J. (1992). The economics of global tourism. Presented at the Fourth World Congress on National Parks and Protected Areas, Caracas, Venezuela, February 10-21, 1992.

Godwin, N. (1991, February). Nature tourists in WWF survey spend more, take longer trips. Travel Weekly.

Handszuh, H. F. (2001, February). Symposium on tourism services. Geneva, Switzerland: World Tourism Organization (WTO).

International Ecotourism Society. (2002). Retrieved June 14, 2002 from www.ecotourism.org

Kutay, K. (1991, March). Ecotourism revisited. The Environmental Journal.

Lindberg, K., Furze, B., Staff, M., and Black, R. (1997). Ecotourism in the Asia-Pacific Region: Issues and outlook. Bennington, VT: The International Tourism Society.

New Travel Ethic. (1995). Worchester, MA: Above the Clouds Trekking.

Munoz, O. (1993). The Ecotourism explosion: Is it radioactive? 1993 World Congress on Adventure Travel and Ecotourism (p. 61). Englewood, CO: Adventure Travel Society.

Pearce, D. (1981). Tourist development. New York: Longman House.

Price, M. (1994, September). A fragile balance. Geographical Magazine. 66(9) 35.

Reingold, L. (1993). Identifying the elusive ecotourist. Going Green: A Supplement to Tour \& Travel News, October 22: 36-37.

Robertson, R.A. (1995). University based education and training programs in ecotourism or nature-based tourism in the USA: A summary report. Summary of Resource, Community, \& Tourism Development Research.

Roe, D. \& Urquhart, P. (2001, May). Pro-poor tourism: Harnessing the world's largest industry for the world's poor.

London: International Institute for Environment and Development.

Tourism after 11 September 2001: Analysis, remedial actions and prospects. Madrid, Spain: World Tourism Organization

Travel Industry Fast Facts Sheet. (1999). Travel Industry Association of America. 


\section{APPENDIX A}

\section{Universities and Colleges Offering Courses in Ecotourism}

Clemson University

Department of Parks, Recreation \& Tourism Management

130 Leholtsky Hall

Clemson, SC 29634-1001

Cornell University

Properties Department

182 Statler Hall

Ithaca, NY 14853

Florida International University

School of Hospitality Management

3000 NE 151 St.

N. Miami, FL 33181

George Washington University

Center for Career Education

2029 K Street, NW, Suite 600

Washington, DC 20006

Hocking College

Ecotourism and Adventure Travel Program

709 College Avenue

Columbus, Ohio 43209

Humboldt State University

Ecotourism Planning \& Management Program

211 Student \& Business Services Building

Arcata, CA 95521-8299

Indiana University, Purdue University, Indianapolis

RHIT Department

ET 205799 W Michigan Street

Indianapolis, IN 46202

Michigan State University

Department of Park, Recreation and Tourism Resources

126 Natural Resources

East Lansing, MI 48824-1222 
New York University

Center for Hospitality, Tourism, and Travel Administration

48 Cooper Square, Room 103

New York, NY 10003

Northern Arizona University

Department of Parks \& Recreation Management

PO Box 15018

Flagstaff, AZ 86011-5018

Oregon State University

Department of Forest Resources

280 Peavy Hall

Corvallis, OR 97331-5703

Penn State University

Recreation and Park Management

215 Mateer Bldg

University Park, PA 16802-1307

San Diego State University

Department of Geography

5500 Campanile Drive

San Diego, CA 92182-4493

Stephen F. Austin State University

Arthur Temple College of Forestry

Box 6109 SFA,

Nacogdoches, Texas 75962

University of New Hampshire

Department of Resource Economics

56 College Rd

Durham, NH 03824

Virginia Polytechnical University

College of Forestry and Wildlife Resources

324 Cheatham hall

Blacksburg, VA 24061-0324

West Virginia University

Recreation, Parks, and Tourism Resources Program

PO Box 6125

Morgantown, WV 26506-6125 


\section{APPENDIX B}

Sample of Ecotour Operators

\begin{tabular}{ll} 
Adventure Life & www.adventure-life.com \\
Discovery Initiatives & www.discoveryinitiatives.com \\
Discovery Travel & www.discoveryl.com \\
\hline Earthbound Adventures & www.earthboundadventures.com \\
\hline Eco Voyager & www.ecovoyager.com \\
\hline Geographic Expeditions & www.geoex.com \\
\hline International Expeditions & www.internationalexpeditions.com \\
\hline Mountain Travel Sobek & www.mtsobek.com \\
Odysseys Unlimited & www.odysseys-unlimited.com \\
\hline Outdoor Travel Adventures & www.campprovincetown.com \\
\hline Wildland Adventures & www.wildland.com
\end{tabular}


